\title{
Kindergarten Teachers' Perception on Basic Movement Skills Understanding Through Rhythmic Gymnastics Movement
}

\author{
Noviria Sukmawati \\ Sport Education \\ Binadarma University \\ Palembang, Indonesia \\ noviria.sukmawati@binadarma.ac.id
}

\author{
Firmansyah Dlis, Ramdan Pelana \\ Sport Education \\ State University of Jakarta \\ Jakarta, Indonesia \\ firmansyahdlis@yahoo.com,ramdanpelana@yahoo.com
}

\begin{abstract}
This study aims to analyze the basic movement needs in rhythmic gymnastics movements on the physical learning of kindergarten children. This research was conducted in Sidomulyo State Kindergarten, At-Taqwa Kindergarten, and Qurrotaayun Kindergarten. The subjects of this study were 20 teachers. The method used in this research is descriptive qualitative research method. This study applied to purposive sampling. Research data were collected by using observation and interview techniques. The findings showed that $100 \%$ of the teachers understood in theory, but they have a lack understanding of the right techniques of children's basic movements. Therefore, it is necessary to have the rhythmic gymnastics movement innovation under the basic movement and motor development of kindergarten children.
\end{abstract}

Keywords: understanding, teacher, basic movement, rhythmic gymnastics

\section{INTRODUCTION}

Perception is a process that is preceded by a sensing process, which is a process of receiving stimulus by individuals through the senses or also called a sensory process [1]. Perception is related to how to look, interpret an object according to the perspective of the person who perceives. Early Childhood Education henceforth Early Childhood Education teacher's perception is the opinion/response of Early Childhood Education teacher that is influenced by knowledge, thinking ability, feelings, and experiences and is individualized. Early Childhood Education teachers' perceptions about the obstacles they experience when implementing learning in the classroom are different. Although aspects that experience the same obstacles, each teacher has a different opinion about the factors that hinder the implementation of learning.

The role of early childhood teachers is more as a mentor or facilitator, and not a presenter of universal knowledge because science cannot be transferred from the teacher to the child without the activity of the child himself. In the learning process, emphasis must be placed on the thinking of the teacher.

Therefore, it is important for teachers to be able to understand children's ways of thinking, develop, and appreciate children's experiences. They also need to understand how children cope with a problem, provide and give the material by the level of cognitive development of children to be more successful in helping children think and shape knowledge, using various learning methods varied that allow children to construct knowledge actively [2]. [3] have the opinion that is very important in choosing a career to become an early childhood educator must know about the development of students, able to create programs that will help each student become a whole individual. The teachers' understanding of learning must be compatible with the child's development. A good understanding will produce maximum learning.

Early Childhood Education is a coaching effort aimed at children from birth until the age of six carried out through the provision of educational stimuli to help physical and spiritual growth and development so that children have the readiness to enter further education. Seen on Peraturan Menteri Pendidikan \& Kebudayaan Republik Indonesia Nomor 146 Tahun 2014, Reference [4] explains that "Early childhood education is a coaching effort aimed at children from birth until the age of 6 (six) carried out through the provision of educational stimuli to help the educational growth and physical and spiritual development so that children have the readiness to enter further education."

Departing from this definition, it can be concluded that early childhood education is education that seeks to foster physical, cognitive, artistic, linguistic, emotional, social, moral and religious aspects of children born to six years through the administration of education in order to have a readiness to learn on the next level of education, including the education of kindergarten children.

Kindergarten education is a formal educational institution for children before entering the next level of education. This institution is considered essential to develop children's potential optimally. Kindergarten Education aims to help students develop a variety of potential, both psychological and physical, including moral and religious values, social, emotion, independence, cognition, language, physical motor, and art, to be ready to enter elementary school education.

According to Bloom [5], understanding is the ability of someone to know or understand something after it is known and remembered. Meanwhile, according to [6] that understanding or comprehension is the level of ability that expects the test takers to be able to understand the meaning or concept, situation, and the facts he knows. Based on the theory that has been stated above, it can be concluded that understanding is an ability to interpret the things contained in theory or concepts learned. Kindergarten teacher's understanding is the ability, the teacher's ability to be able to define, master either theory or practice, and master it by understanding the meaning of the learning material being taught. 
The teacher's role is very influential in the

The particular material presented on Kindergarten Education is to improve the kinesthetic of basic movements, including through movement and song, namely gymnastics. There are several forms of gymnastics; one of them is rhythmic gymnastics. Gymnastics did channelize a sense of art or a sense of beauty to foster and enhance the movement art. The emphasized points that must be given to the rhythmic gymnastics are the rhythm, body flexibility, and continuity of movement [7].

Rhythmic gymnastics is "gymnastics that follow the music rhythm or rhythmic free practice" [8]. He defines the rhythmic gymnastics as, "Sports that use hand tools combined with variations of body movement elements, in practice, children will feel happy and interested because they move with their body combined with equipment accompanied by music" [9].

Gymnastics is also considered as a physical activity that is very suitable to be a tool of physical education because it is considered capable of contributing to the development of motor quality and physical quality of children at once. Gymnastics skills are always built on basic locomotor, nonloco motor, and manipulative skills.

Besides having benefits in the development of a child's brain, motion and song activities contribute significantly to the brain development of a kindergarten child. Kindergarten children can memorize things, undoubtedly with proper stimulation in order to be going to have benefit for themselves. Through gymnastic movements, the child will be free to express. Therefore, the children will find new experiences, and by following the rhythm, the children will be freer to move, imagine, and be brave to face new challenges.

Related to the benefits of gymnastics as physical activity of movement and song, in [10] argued that: "Physical activity of movement and song can make a significant contribution to balance the brain of early childhood, by combining physical activity (sports) and listening to music or singing activities, it can also help their brain development.

Children who follow the song by moving all parts of the body can be useful to stimulate the functioning of both the left brain and the right brain. Also, the benefit of rhythmic gymnastics for kindergarten children is the most useful activity for developing physical components and motor ability [11].

The standard principle of kindergarten children's motor development is that there are changes both physically and psychologically following the period of its growth. The values contained in motor development of kindergarten children include gaining meaningful experience, the rights and opportunities to do activities, the balance of body and soul, and being able to play a role to be themselves.

Based on the characteristics and structure of the movement, gymnastics is very suitable to be designed and developed as a medium of learning in physical education (physical motor) because it has many variations in its movement structure. Lots of variety and movement structures will enrich the children's movement treasury. The direct movement impacts the enhancement of children's learning activities in the teaching and learning process. If the children's learning activity is high, the children's physical fitness will be better. implementation of learning because of its role as a mediator in the learning implementation in kindergarten. A wealth of motion is needed for children to develop their motor quality so that it is expected to have an impact on improving nonmotor quality. Thus it is needed for the teacher to understand the correct basic movement activities so that the learning objectives in the basic movement skills of children are achieved. Based on the description above, the researcher aims to analyze the perception of kindergarten teachers' understanding of the basic movement skills of kindergarten children through rhythmic gymnastics movements.

\section{METHOD}

\section{A. Research Method}

This research is descriptive qualitative research. This research was conducted at Sidomulyo State Kindergarten, At-Taqwa Kindergarten, Qurrotaayun Kindergarten. The subjects of this study were 20 teachers. The research used in the form of an interview instrument for teachers to obtain information on the understanding of the children's basic movements and rhythmic gymnastics movements. This study applied data analysis techniques, namely, qualitative descriptive analysis. Reference [12] states that by using this descriptive technique, the researcher will describe or depict the data that have been collected about an object in order to obtain conclusions.

The results of the research describe; 1) The teachers' understanding of basic movements and rhythmic gymnastics movements, 2) The benefits of basic movements in rhythmic gymnastics movements on the physical learning of kindergarten children. Data analysis techniques used statistical tests, and then it was classified in quantitative research. The scores obtained were analyzed using descriptive statistical techniques as outlined in the form of a percentage [13], while the percentage formula is as follows:

$$
\% \text { Score interpretation }=\frac{\Sigma \text { acquisition score }}{\Sigma \text { maximum score }}
$$

Referring to the formula above, the calculation results obtained were presented from each item of questions, the next step was to describe each item in the questionnaire and determine the classification of students' perceptions, and then the writer used guidelines with a range of $20 \%$. Here is a table of percentage interpretation criteria of scores:

TABLE I. SCORES PERCENTAGE INTERPRETATION CRITERIA

\begin{tabular}{|l|l|}
\hline \multicolumn{1}{|c|}{$\%$ Interpretation Score } & \multicolumn{1}{c|}{ Score Category } \\
\hline $0-20 \%$ & Very weak \\
\hline $21-40 \%$ & Weak (bad) \\
\hline $41-60 \%$ & Sufficient (moderate) \\
\hline $61-80 \%$ & Strong (good) \\
\hline $81-100 \%$ & Very Strong (very good) \\
\hline
\end{tabular}

\section{RESUlTS AND DISCUSSION}

The results of the study discussed the results of calculating the frequency of the answers, the average score of the percentage of teachers' answers regarding two indicators, namely: 1) Teachers' understanding of basic movements and rhythmic gymnastics movements; 2) The benefits of basic movement in rhythmic gymnastics movements on physical motor learning. The following were the results of interviews of 20 teachers about teachers' 
understanding of basic movements and rhythmic gymnastics movements. Here is a table of results of interviews with kindergarten teachers:

TABLE II. THE RESULTS OF INTERVIEWS WITH KINDERGARTEN TEACHERS

\begin{tabular}{|l|l|}
\hline \multicolumn{1}{|c|}{ Questions } & \multicolumn{1}{c|}{ Answers } \\
\hline $\begin{array}{l}\text { Teachers' } \\
\text { basic movements } \\
\text { and rhythmic } \\
\text { gymnastics } \\
\text { movements. }\end{array}$ & $\begin{array}{l}\text { Of the 20 teachers, 100\% of the teachers } \\
\text { answered that they understood basic movements } \\
\text { in the rhythmic gymnastics movements; } \\
\text { however, their understanding was limited to } \\
\text { theoretical knowledge, while in practice, the } \\
\text { teachers were lack understanding of the } \\
\text { correctness of its movement technique. It can be } \\
\text { seen that the children's basic movement skills are } \\
\text { very important for their development, seen from } \\
\text { the elements of maturity and control of body } \\
\text { movements. Movement learning is the basic } \\
\text { foundation in understanding the mechanism of } \\
\text { body movement. The teachers' understanding of } \\
\text { the function of children's basic movement is the } \\
\text { children can do the movements correctly on the } \\
\text { implementation of the movement itself so that it } \\
\text { can reduce the children's injury. }\end{array}$ \\
\hline $\begin{array}{l}\text { The benefits of } \\
\text { basic movement in } \\
\text { rhythmic } \\
\text { gymnastics } \\
\text { movements } \\
\text { physical } \\
\text { learning. }\end{array}$ & $\begin{array}{l}\text { Of the 20 teachers, 100\% of the teachers } \\
\text { answered that they understood, but the teachers' } \\
\text { understanding was limited to the benefits for } \\
\text { physical health. Though, there are many benefits } \\
\text { gained after doing a series of rhythmic } \\
\text { gymnastics movements correctly and adequately. } \\
\text { They are such as improving heart health, helping } \\
\text { to lose weight, burning fat and calories, } \\
\text { increasing motor skills to optimize brain } \\
\text { function, enhancing self-confidence, causing } \\
\text { better social interaction, raising children's } \\
\text { feelings to become more excited and happy, and } \\
\text { increasing creativity. } \\
\text { Through gymnastic movements, the children will } \\
\text { be free to express so that they will find new } \\
\text { experiences, and by following the rhythm, the } \\
\text { children will be freer to move, imagine and be } \\
\text { brave to face new challenges. }\end{array}$ \\
\hline
\end{tabular}

Following are the results of the research from the teachers' statement about understanding the basic movement skills of kindergarten children through rhythmic gymnastics movements:

TABLE III. THE RESULTS OF PERCEPTIONS OF TEACHERS' UNDERSTANDING

\begin{tabular}{|c|c|c|c|c|c|c|c|}
\hline $\begin{array}{c}\text { Statement } \\
\text { item }\end{array}$ & Sp & $\mathbf{P}$ & $\mathbf{K p}$ & $\mathbf{T p}$ & Score & $\mathbf{( \% )}$ & Category \\
\hline 1 & 20 & 0 & 0 & 0 & 80 & $100 \%$ & Very good understanding \\
\hline 2 & 17 & 3 & 0 & 0 & 77 & $96.30 \%$ & Very good understanding \\
\hline 3 & 20 & 0 & 0 & 0 & 80 & $100 \%$ & Very good understanding \\
\hline 4 & 16 & 4 & 0 & 0 & 76 & $95 \%$ & Very good understanding \\
\hline 5 & 14 & 6 & 0 & 0 & 74 & $92.50 \%$ & Very good understanding \\
\hline 6 & 5 & 15 & 0 & 0 & 65 & $81.30 \%$ & Very good understanding \\
\hline 7 & 7 & 13 & 0 & 0 & 67 & $83.40 \%$ & Very good understanding \\
\hline 8 & 10 & 10 & 0 & 0 & 70 & $87.50 \%$ & Very good understanding \\
\hline 9 & 12 & 8 & 0 & 0 & 72 & $90 \%$ & Very good understanding \\
\hline 10 & 20 & 20 & 0 & 0 & 80 & $100 \%$ & Very good understanding \\
\hline Average & & & & 74.1 & $92.60 \%$ & Very good understanding \\
\hline
\end{tabular}

Based on the table above, the teachers have been very familiar with the material of basic kindergarten children's movement skills through rhythmic gymnastics movements. Statement items are about basic movement skills consisting of locomotor motion, non-loco motor motion, manipulative motion, the benefits of basic movements, and rhythmic gymnastics movements. The average score of teachers' understanding of basic kindergarten children's movement skills obtained through rhythmic gymnastics movements is $92.6 \%$. It means that the teachers of Sidomulyo State Kindergarten, At-Taqwa Kindergarten, and Qurrotaayun Kindergarten have already understood basic movement skills through rhythmic gymnastics movements.

\section{CONCLUSION}

Based on this, the teacher needs to understand the correct basic movement skills in doing a series of rhythmic gymnastics movements to achieve the objectives of the movement carried out. So that, teachers are expected to be able to make a rhythmic gymnastics movement that is arranged based on the themes and characteristics of the children's movements that are appropriate to their age and can provide movement experience with the correct techniques.

Therefore, the teacher is expected to be able to do basic movements with the right techniques. This research is expected to contribute to further research to be able to develop basic movement skills through a series of rhythmic gymnastics movements that are appropriate to the characteristics of student development.

\section{REFERENCES}

[1] W. Bimo Pengantar psikologi Umum. Jakarta: Penerbit Andi, 2004

[2] S. Sujiono. Konsep Dasar Pendidikan AnakUsia Dini. Jakarta: Indeks, 2013.

[3] C. Houston-Wilson, J. M. Dunn, H. Van Der Mars, and J. McCubbin, "The effect of peer tutors on motor performance in integrated physical education classes," Adapted Physical Activity Quarterly, vol. 14, no.4, 1997, pp.298-313.

[4] Peraturan MenteriPendidikan \& Kebudayaan Republik Indonesia Nomor 146 Tahun 2014.

[5] D. Dimyati, BelajardanPembelajaran. Jakarta: RinekaCipta, 2006.

[6] N. Purwanto, Prinsip-prinsip dan teknik Evaluasi Pengajaran. Bandung: Remaja Rosdakarya, 2012.

[7] A. Husnul, Bergembira Melakukan Senam Irama. Jakarta: Wardah Imu, 2011.

[8] T. Sukarma, Senam Ritmik, Bentuk-BentukTugas Ajar dan Pembelajarannya. Jakarta:Depdiknas, 2001.

[9] H. C. Palmer. Teaching Rhytmic Gymnastics A Developmentally Appropriate Approach (United State of Amerika: Human Kinetics, 2003.

[10] G. D. Pradipta, "Strategi Peningkatan Keterampilan Gerak Untuk Anak Usia Dini Taman Kanak-Kanak B," Jendela Olahraga, Vol. 2, No. 1, 2017.

[11] A. Mahendra, PermainanAnak Dan AktivitasRitmik. Jakarta: Erlangga, 2010.

[12] S. Sugiyono, Metode Penelitian Kuantitatif Kualitatif dan R\&D. Bandung: ALFABETA, 2008.

[13] N. Sudjana, Penelitian Hasil Proses Belajar Mengajar. Bandung: Remaja Rosda Karya, 2012. 